\title{
A Study of Adoption Pattern of Recommended Practices for Major Vegetable Crops in Flood Prone Areas of Lakhimpur District of Assam, India
}

\author{
Kangkana Borah ${ }^{\text {** }}$, Pabitra Kumar Das ${ }^{2}$ and Indrajit Barman ${ }^{2}$ \\ ${ }^{1}$ ATMA, Biswanath Block, District Agicultural Office, Biswanath Chariali, India \\ ${ }^{2}$ Department of Extension Education, BN College of Agriculture, \\ Biswanath Chariali, Assam Agricultural University, Jorhat-13, Assam, India
}

*Corresponding author

\section{A B S T R A C T}

\begin{tabular}{|l|}
\hline Key w or d s \\
Adoption pattern, \\
Vegetables, \\
Cultivations, \\
Lakhimpur, \\
Narayanpur \\
\hline Article Info \\
\hline Accepted: \\
26 May 2020 \\
Available Online: \\
10 June 2020 \\
\hline \hline
\end{tabular}

The present work was to determine the extent of adoption of recommended package of practices of major vegetable crops in flood prone areas of Lakhimpur District of Assam. The study area covered the North Lakhimpur and Narayanpur agricultural sub-divisions of the district and 60 vegetable growers from 4 flood prone villages constituted the sample size. Majority of the farmers were found to have medium overall extent of adoption $(45.00 \%)$ followed by low overall extent of adoption $(30.00 \%)$ and high overall extent of adoption $(25.00 \%)$ of recommended practices of four major vegetables. In tomato cultivation, majority of the farmers were had low extent of adoption (53.33\%) followed by medium extent of adoption (33.33\%) and high extent of adoption (13.34\%) In cabbage cultivation, majority of the farmers were found with medium extent of adoption $(60.00 \%)$, followed by low extent of adoption (38.33\%) and high extent of adoption (1.67\%). In cauliflower cultivation, majority of the farmers had low extent of adoption (53.33\%), followed by medium extent of adoption (41.67\%) and high extent of adoption $(5.00 \%)$. In potato cultivation, majority of the farmers of were found with medium extent of adoption $(53.33 \%)$, followed by low extent of adoption (41.67\%) and high extent of adoption $(5.00 \%)$.

\section{Introduction}

Cultivation of vegetables and fruits is now considered as a viable commercial proposition. With the introduction of liberal trade policies, prospects for export of fruits and vegetables have improved. Vegetables provide a good source of income to the growers and play an important part in human nutrition. They are quick growing and yield immediate returns to the growers. Vegetable crops play an important role in diversification of agriculture and can help conserve the everdepleting underground water.

The country has witnessed tremendous progress in vegetable production, especially during the post green revolution period. They have a vital role to play on the food front as they reduce the demand of cereals. 
Vegetable crops are short duration and therefore more number of crops can be grown per year. Due to shrinkage of agricultural land, urbanization and industrialization, cultivation of vegetable crops will be more economic. Vegetable crops also play an important role in diversification of agriculture and can help conserve the ever-depleting underground water. Per capita availability of vegetables in India is $357 \mathrm{gm} /$ person/day, which helps in fighting malnutrition.

Assam with its vast network of rivers is prone to natural disasters like flood and erosion which has a negative impact on overall development of the state. The two Main Rivers of the state Brahmaputra and Barak along with their tributaries are fed with excessive rainfall during the monsoon season. This creates severe flood each year causing widespread damage to the agriculture, properties, transportation and also human life. According to Rastriya Barh Ayog (RBA) the flood prone area of the state is 31.05 lakh hectares (about $39.58 \%$ of the total land of Assam). This area is about $9.40 \%$ of total flood prone area of the country. The earthquake of 1950's is considered to be one of the reasons of devastating flood in the state as it reduced the water-carrying capacity of the rivers. The most destructive floods were faced by the people in Assam were in 1954, 1962, 1972, 1984, 1988, 1998, 2002, 2004, 2012, 2014 and 2015 (NEDFi Databank). Most of the areas of Assam are prone to flood which is major problem for low crop production. Major flood prone districts of the states are -Lakhimpur, Dhemaji, Borpeta, Sonitpur followed by Jorhat, Dhubri, Kokrajhar, Tinsukia, Goalpara and Dibrugarh.

\section{Materials and Methods}

Rogers (1983) defined adoption as a decision to make full use of an innovation as the best course of action available. In the present study, 'extent of adoption' was treated as the dependent variable and was computed by adding the scores obtained by the respondents on individual practices. The extent of adoption was measured by following the procedure used by Baruah (2004). Extent of adoption of recommended package of practices of vegetable cultivation by the farmers has been conceived as the actual use of recommended vegetable cultivation practices against three response categories, viz., full adoption, partial adoption and no adoption. If a farmer was found to use a given practice as per recommendation, it was considered as 'full adoption' which was assigned a score of 2. A deviation from the recommended practice was considered as 'partial adoption' which was assigned a score of 1. Farmers who did not follow the recommended practice at all was considered as 'no adoption' and assigned a score of 0 . In the present study, extent of adoption was studied for four selected major vegetable crops, viz. Cabbage, Cauliflower, Tomato and Potato. For each of these crops, the extent of adoption was calculated for 14 selected cultivation practices as recommended by Assam Agricultural University and Department of Agriculture, govt. of Assam.

The total score obtained by a respondent was calculated by adding the adoption scores for all the practices followed by that respondent. On the basis of the mean $(\overline{\mathrm{X}})$ and standard deviations (S.D.) of obtained scores, respondents were classified into three categories as follows:

\begin{tabular}{|c|c|}
\hline $\begin{array}{c}\text { Categories } \\
\text { Low extent of } \\
\text { adoption }\end{array}$ & Bcore range \\
\hline $\begin{array}{c}\text { Medium extent of }(\overline{\mathrm{X}}-1 . \mathrm{S} . \mathrm{D} .) \\
\text { adoption } \\
\begin{array}{c}\text { High extent of } \\
\text { adoption }\end{array}\end{array}$ & Above $(\overline{\mathrm{X}}+1$. S. D. $)$ \\
\hline
\end{tabular}


Statistical analysis and interpretation of data

The collected data were coded, tabulated and analyzed in accordance with the objectives of the present study by using appropriate statistical techniques. The statistical techniques along with their uses are described below:

Frequency distribution: It is a representation which displays the number of observations within a given interval.

Percentage: It is a fraction expressed with 100 as its denominator. It is used to any set of data for comparison.

Mean: It is arithmetic average and was used to measure the type of the observation as a whole.

Standard deviation: To find out the extent of variability shown by the variables, i.e., the dispersion of the variables around the mean, standard deviation (S.D.) was used.

Co-efficient of variation (C.V.): This index was used to find out the relative variability or dispersion of a given set of scores.

\section{Results and Discussion}

\section{Extent of adoption of recommended practices of major vegetables}

\section{Extent of adoption of recommended practices of tomato}

It is evident from Table 1 and Figure 1 that majority of the farmers $(53.33 \%)$ had low extent of adoption, followed by 33.33 per cent of the farmers having medium extent of adoption. Only 13.34 per cent of the farmers had high extent of adoption. The value of coefficient of variation (31.52) indicated that the farmer respondents were relatively homogeneous with respect to their extent of adoption of recommended practices of tomato cultivation.
In practice wise adoption, it is evident from table 2 that majority of them $(35.00 \%)$ fully adopted the recommended time of sowing, followed by 31.67 per cent respondents who fully adopted the recommended variety. Only 8.33 per cent of them were full adopters of the recommended spacing and disease control practices. Majority $(66.67 \%)$ of the respondents of flood prone areas partially adopted the recommended irrigation practices, followed by 55.00 per cent respondents who partially adopted the recommended seed rate, seed treatment and pest control practices. Similarly recommended spacing was partially adopted by 48.33 per cent of the respondents. Similarly 53.33 per cent of the respondents did not adopt the recommended FYM/ compost / bio-fertilizer and method of application of chemical fertilizer.

\section{Extent of adoption of recommended practices of cabbage}

It is evident from Table 2 and Figure 1 that majority of the farmers $(60.00 \%)$ had medium extent of adoption, followed by 38.33 per cent of the farmers having low extent of adoption. Only 1.67 percent of the farmers had high extent of adoption. The value of co-efficient of variation (21.51) indicated that the farmer respondents of flood prone areas were relatively homogeneous with respect to their extent of adoption of recommended practices of cabbage cultivation.

In practice wise adoption, it is evident from table 2 that majority of them $(30.00 \%)$ were full adopters of the recommended variety, followed by 21.67 per cent respondents who fully adopted the recommended time of sowing. Only 16.67 per cent of them fully adopted the recommended pest control practices. Majority of the respondents of flood prone areas $(66.67 \%)$ were partial adopters of the recommended seed rate, followed by 61.67 per cent respondents who partially adopted the recommended spacing. 
Recommended method of application of chemical fertilizer was partially adopted by 58.33 per cent of the respondents.

\section{Extent of adoption of recommended practices of cauliflower}

It is evident from Table 3 and Figure 1 that majority of farmers $(53.33 \%)$ had low extent of adoption, followed by 41.67 per cent of the farmers having medium extent of adoption. Only 5.00 per cent of the farmers had high extent of adoption. The value of co-efficient of variation (20.41) indicated that the farmer respondents of flood prone areas were relatively homogeneous with respect to their extent of adoption of recommended practices of cauliflower cultivation.

In practice wise adoption, it is evident from table 2 that majority (33.33\%) of them were full adopters of the recommended variety, followed by 25.00 per cent respondents who fully adopted the recommended time of sowing. Only 11.67 per cent of them fully adopted the recommended FYM / compost / bio-fertilizer.

Similarly, majority of the respondents of flood prone areas $(56.67 \%)$ were partial adopters of the recommended irrigation practices, followed by 51.67 per cent respondents who partially adopted the recommended dose of chemical fertilizer. Half of them $(50.00 \%)$ partially adopted the recommended disease control measures. Similarly, 56.67 per cent of the respondents did not adopt the recommended method of application of chemical fertilizer.

\section{Extent of adoption of recommended practices of potato}

It is evident from Table 4 and Figure 1 that majority of the farmers $(53.33 \%)$ had medium extent of adoption, followed by 41.67 per cent of the respondents having low extent of adoption. Only 5.00 per cent of the respondents had high extent of adoption. The value of co-efficient of variation (29.27) indicated that the flood prone farmer respondents were relatively homogeneous with respect to their extent of adoption of recommended practices of potato cultivation.

In practice wise adoption, it is evident from table 2 that majority of them $(35.00 \%)$ were full adopters of the recommended variety and time of sowing, followed by 13.33 per cent respondents who fully adopted the recommended disease control measures. Only 10.00 per cent of them fully adopted the recommended pest control measures.

Similarly, majority of the respondents of flood prone areas (61.67\%) partially adopted the recommended disease control practice, followed by 58.33 per cent respondents who partially adopted the recommended seed rate and spacing and 55.00 per cent of the respondents who partially adopted the recommended dose of chemical fertilizer.

Over all extent of adoption of recommended practices of selected major vegetables

Majority of the farmers $(45.00 \%)$ had medium extent of adoption, followed by 30.00 per cent of the farmers having low extent of adoption of recommended practices of selected major vegetables. Only 25.00 per cent of the farmers had high extent of adoption. The value of coefficient of variation (55.59) indicated that the farmer respondents of flood prone areas were relatively heterogeneous with respect to their extent of adoption of recommended package of practices of selected major vegetables.

Problems faced by the farmers of flood prone areas in adopting recommended practices of major vegetables

'No opportunity for training on scientific vegetable cultivation practices' was the most 
important problem faced by the farmers of flood prone areas in adopting recommended practices of major vegetables as reported by 86.66 per cent of the respondents of flood prone areas. 'Lack of technical guidance from extension agents' was the second important problem faced by the farmers of flood prone areas in adopting recommended practices of major vegetables as reported by 70.00 per cent of the respondents of flood prone areas. 'Inadequate irrigation facilities' was the third important problem faced by the farmers of flood prone areas in adopting recommended practices of major vegetables as reported by 68.33 per cent of the respondents of flood free areas. 'High cost of chemicals' (66.66\%), 'Lack of market information' (71.66\%), and 'Non-availability of quality seeds in proper time' $(58.33 \%)$ were the next three important problems faced by them which were ranked fourth, fifth and sixth.

The other important problems faced by the farmers of flood prone areas in order of importance were 'Non-availability of proper farm implements for mechanization' (56.66\%), 'Threat from stray animals' $(51.66 \%)$, 'Siltation in the field due to flood $(55.00 \%)$, 'No facility for soil testing' $(45.00 \%)$, 'High cost of hired labour' $(43.33 \%)$, 'Difficulty to take up commercial cultivation due to fragmentation of land $(23.33 \%)$, 'Ignorance to select suitable crops according to soil type (31.66\%) and 'Degradation of soil health due to continued use of chemical fertilizer $(25.00 \%)$.

Table.1a Distribution of respondents according to extent of adoption of recommended practices of tomato

\begin{tabular}{|c|c|}
\hline Categories & No of farmers \\
\hline $\begin{array}{c}\text { Low extent of adoption } \\
\text { (Between } \mathbf{0 - 8 . 4 3 )}\end{array}$ & 32 \\
\hline $\begin{array}{c}\text { Medium extent of adoption } \\
\text { (Between 8.44-13.91) }\end{array}$ & 20 \\
\hline High extent of adoption & $(33.33)$ \\
\hline (>13.91) & 8 \\
\hline Total & $(13.34)$ \\
\hline Mean & 60 \\
\hline S.D. & $(100.00)$ \\
\hline C.V. & 8.12 \\
\hline
\end{tabular}


Table.1b Distribution of respondents according to extent of adoption of recommended practices of cabbage

\begin{tabular}{|c|c|}
\hline Categories & No of farmers \\
\hline $\begin{array}{c}\text { Low extent of adoption } \\
\text { (Between 0-9.27) }\end{array}$ & 23 \\
\hline $\begin{array}{c}\text { Medium extent of adoption } \\
\text { (Between 9.28-12.49) }\end{array}$ & $(38.33)$ \\
\hline High extent of adoption & 36 \\
$(>\mathbf{1 2 . 4 9 )}$ & $(60.00)$ \\
\hline Total & 1 \\
& $(1.67)$ \\
\hline Mean & 60 \\
\hline S.D. & $(100.00)$ \\
\hline C.V. & 7.25 \\
\hline
\end{tabular}

Table.1c Distribution of respondents according to extent of adoption of recommended practices of cauliflower

\begin{tabular}{|c|c|}
\hline Categories & No of farmers \\
\hline $\begin{array}{c}\text { Low extent of adoption } \\
\text { (Between 0-8.59) }\end{array}$ & 32 \\
\hline $\begin{array}{c}\text { Medium extent of adoption } \\
\text { (Between 8.60-12.17) }\end{array}$ & $(53.33)$ \\
\hline High extent of adoption & 25 \\
$(>\mathbf{1 2 . 1 7 )}$ & $(41.67)$ \\
\hline Total & 3 \\
& $(5.00)$ \\
\hline Mean & 60 \\
\hline S.D. & $(100.00)$ \\
\hline C.V. & 7.20 \\
\hline
\end{tabular}

Table.1d Distribution of respondents according to extent of adoption of recommended practices of potato

\begin{tabular}{|c|c|}
\hline Categories & No of farmers \\
\hline $\begin{array}{c}\text { Low extent of adoption } \\
\text { (Between 0-9.13) }\end{array}$ & 25 \\
\hline $\begin{array}{c}\text { Medium extent of adoption } \\
\text { (Between 9.14-13.85) }\end{array}$ & $(41.67)$ \\
\hline High extent of adoption & 32 \\
$(>\mathbf{1 3 . 8 5})$ & $(53.33)$ \\
\hline Total & 3 \\
\hline Mean & $600)$ \\
\hline S.D. & $(100.00)$ \\
\hline C.V. & 7.55 \\
\hline
\end{tabular}


Table.2 Practice wise distribution of respondents according to overall extent of adoption of recommended practices of four major vegetables

\begin{tabular}{|c|c|c|c|c|c|c|c|c|c|c|c|c|c|}
\hline \multirow[t]{2}{*}{ Sl.no } & \multirow[t]{2}{*}{ Practices } & \multicolumn{3}{|c|}{ Tomato } & \multicolumn{3}{|c|}{ Cabbage } & \multicolumn{3}{|c|}{ Cauliflower } & \multicolumn{3}{|c|}{ Potato } \\
\hline & & FA & PA & NA & FA & FA & PA & NA & FA & FA & PA & NA & FA \\
\hline 1 & Variety & $\begin{array}{c}19 \\
(31.67)\end{array}$ & $\begin{array}{c}14 \\
(23.33)\end{array}$ & $\begin{array}{c}27 \\
(45.00)\end{array}$ & $\begin{array}{c}18 \\
(30.00)\end{array}$ & $\begin{array}{c}21 \\
(35.00)\end{array}$ & $\begin{array}{c}21 \\
(35.00)\end{array}$ & $\begin{array}{c}20 \\
(33.33)\end{array}$ & $\begin{array}{c}15 \\
(25.00)\end{array}$ & $\begin{array}{c}25 \\
(41.67)\end{array}$ & $\begin{array}{c}21 \\
(35.00)\end{array}$ & $\begin{array}{c}18 \\
(30.00)\end{array}$ & $\begin{array}{c}21 \\
(35.00)\end{array}$ \\
\hline 2 & Seed rate & $\begin{array}{c}1 \\
(1.67)\end{array}$ & $\begin{array}{c}33 \\
(55.00)\end{array}$ & $\begin{array}{c}26 \\
(43.33)\end{array}$ & $\begin{array}{c}4 \\
(6.67)\end{array}$ & $\begin{array}{c}40 \\
(66.67)\end{array}$ & $\begin{array}{c}16 \\
(26.66)\end{array}$ & $\begin{array}{c}3 \\
(5.00)\end{array}$ & $\begin{array}{c}28 \\
(46.67)\end{array}$ & $\begin{array}{c}29 \\
(48.33)\end{array}$ & $\begin{array}{c}2 \\
(3.33)\end{array}$ & $\begin{array}{c}35 \\
(58.33)\end{array}$ & $\begin{array}{c}23 \\
(38.33)\end{array}$ \\
\hline 3 & Time of sowing & $\begin{array}{c}21 \\
(35.00)\end{array}$ & $\begin{array}{c}14 \\
(23.33)\end{array}$ & $\begin{array}{c}25 \\
(41.67)\end{array}$ & $\begin{array}{c}13 \\
(21.67)\end{array}$ & $\begin{array}{c}26 \\
(43.33)\end{array}$ & $\begin{array}{c}21 \\
(35.00)\end{array}$ & $\begin{array}{c}15 \\
(25.00)\end{array}$ & $\begin{array}{c}27 \\
(45.00)\end{array}$ & $\begin{array}{c}18 \\
(30.00)\end{array}$ & $\begin{array}{c}21 \\
(35.00)\end{array}$ & $\begin{array}{c}16 \\
(26.67)\end{array}$ & $\begin{array}{c}23 \\
(38.33)\end{array}$ \\
\hline 4 & Spacing & $\begin{array}{c}5 \\
(8.33)\end{array}$ & $\begin{array}{c}29 \\
(48.33)\end{array}$ & $\begin{array}{c}26 \\
(43.33)\end{array}$ & $\begin{array}{c}2 \\
(3.33)\end{array}$ & $\begin{array}{c}37 \\
(61.67)\end{array}$ & $\begin{array}{c}21 \\
(35.00)\end{array}$ & $\begin{array}{c}2 \\
(3.33)\end{array}$ & $\begin{array}{c}15 \\
(25.00)\end{array}$ & $\begin{array}{c}43 \\
(71.67)\end{array}$ & $\begin{array}{c}5 \\
(8.33)\end{array}$ & $\begin{array}{c}35 \\
(58.33)\end{array}$ & $\begin{array}{c}20 \\
(33.33)\end{array}$ \\
\hline 5 & Seed treatment & $\begin{array}{c}0 \\
(0.00)\end{array}$ & $\begin{array}{c}33 \\
(55.00)\end{array}$ & $\begin{array}{c}27 \\
(45.00)\end{array}$ & $\begin{array}{c}5 \\
(8.33)\end{array}$ & $\begin{array}{c}33 \\
(55.00)\end{array}$ & $\begin{array}{c}22 \\
(36.67)\end{array}$ & $\begin{array}{c}0 \\
(0.00)\end{array}$ & $\begin{array}{c}0 \\
(0.00)\end{array}$ & $\begin{array}{c}120 \\
(100.00)\end{array}$ & $\begin{array}{c}5 \\
(8.33)\end{array}$ & $\begin{array}{c}20 \\
(33.33)\end{array}$ & $\begin{array}{c}35 \\
(58.33)\end{array}$ \\
\hline 6 & $\begin{array}{l}\text { FYM/Compost/ } \\
\text { Bio-Fertilizer }\end{array}$ & $\begin{array}{c}1 \\
(1.67)\end{array}$ & $\begin{array}{c}27 \\
(45.00)\end{array}$ & $\begin{array}{c}32 \\
(53.33)\end{array}$ & $\begin{array}{c}0 \\
(0.00)\end{array}$ & $\begin{array}{c}28 \\
(46.67)\end{array}$ & $\begin{array}{c}32 \\
(53.33)\end{array}$ & $\begin{array}{c}7 \\
(11.67)\end{array}$ & $\begin{array}{c}27 \\
(45.00)\end{array}$ & $\begin{array}{c}26 \\
(43.33)\end{array}$ & $\begin{array}{c}5 \\
(8.33)\end{array}$ & $\begin{array}{c}30 \\
(50.00)\end{array}$ & $\begin{array}{c}25 \\
(41.66)\end{array}$ \\
\hline 7 & $\begin{array}{l}\text { Dose of chemical } \\
\text { fertilizer }\end{array}$ & $\begin{array}{c}1 \\
(1.67) \\
\end{array}$ & $\begin{array}{c}28 \\
(46.67)\end{array}$ & $\begin{array}{c}31 \\
(51.67)\end{array}$ & $\begin{array}{c}0 \\
(0.00)\end{array}$ & $\begin{array}{c}30 \\
(50.00)\end{array}$ & $\begin{array}{c}30 \\
(50.00)\end{array}$ & $\begin{array}{c}0 \\
(0.00)\end{array}$ & $\begin{array}{c}31 \\
(51.67)\end{array}$ & $\begin{array}{c}29 \\
(48.33)\end{array}$ & $\begin{array}{c}0 \\
(0.00)\end{array}$ & $\begin{array}{c}33 \\
(55.00)\end{array}$ & $\begin{array}{c}27 \\
(45.00)\end{array}$ \\
\hline 8 & $\begin{array}{ll}\text { Method } & \text { of } \\
\text { application } & \text { of } \\
\text { chemical } & \\
\text { fertilizer } & \end{array}$ & $\begin{array}{c}2 \\
(3.33)\end{array}$ & $\begin{array}{c}26 \\
(43.33)\end{array}$ & $\begin{array}{c}32 \\
(53.33)\end{array}$ & $\begin{array}{c}4 \\
(6.67)\end{array}$ & $\begin{array}{c}35 \\
(58.33)\end{array}$ & $\begin{array}{c}21 \\
(35.00)\end{array}$ & $\begin{array}{c}5 \\
(8.33)\end{array}$ & $\begin{array}{c}21 \\
(35.00)\end{array}$ & $\begin{array}{c}34 \\
(56.67)\end{array}$ & $\begin{array}{c}3 \\
(5.00)\end{array}$ & $\begin{array}{c}28 \\
(46.67)\end{array}$ & $\begin{array}{c}29 \\
(48.33)\end{array}$ \\
\hline 9 & Irrigation & $\begin{array}{c}0 \\
(0.00)\end{array}$ & $\begin{array}{c}40 \\
(66.67)\end{array}$ & $\begin{array}{c}20 \\
(33.33)\end{array}$ & $\begin{array}{c}0 \\
(0.00)\end{array}$ & $\begin{array}{c}34 \\
(56.67)\end{array}$ & $\begin{array}{c}26 \\
(43.33)\end{array}$ & $\begin{array}{c}0 \\
(0.00) \\
\end{array}$ & $\begin{array}{c}34 \\
(56.67)\end{array}$ & $\begin{array}{c}26 \\
(43.33)\end{array}$ & $\begin{array}{c}3 \\
(5.00)\end{array}$ & $\begin{array}{c}24 \\
(40.00)\end{array}$ & $\begin{array}{c}33 \\
(55.00)\end{array}$ \\
\hline 10 & Weeding & $\begin{array}{c}2 \\
(3.33)\end{array}$ & $\begin{array}{c}25 \\
(41.67)\end{array}$ & $\begin{array}{c}33 \\
(55.00)\end{array}$ & $\begin{array}{c}0 \\
(0.00)\end{array}$ & $\begin{array}{c}34 \\
(56.67)\end{array}$ & $\begin{array}{c}26 \\
(43.33)\end{array}$ & $\begin{array}{c}3 \\
(5.00)\end{array}$ & $\begin{array}{c}24 \\
(40.00)\end{array}$ & $\begin{array}{c}33 \\
(55.00)\end{array}$ & $\begin{array}{c}5 \\
(8.33)\end{array}$ & $\begin{array}{c}30 \\
(50.00)\end{array}$ & $\begin{array}{c}25 \\
(41.66)\end{array}$ \\
\hline 11 & $\begin{array}{l}\text { Application of } \\
\text { growth regulator }\end{array}$ & $\begin{array}{c}0 \\
(0.00)\end{array}$ & $\begin{array}{c}0 \\
(0.00)\end{array}$ & $\begin{array}{c}120 \\
(100.00)\end{array}$ & $\begin{array}{c}0 \\
(0.00)\end{array}$ & $\begin{array}{c}0 \\
(0.00)\end{array}$ & $\begin{array}{c}120 \\
(100.00)\end{array}$ & $\begin{array}{c}0 \\
(0.00)\end{array}$ & $\begin{array}{c}0 \\
(0.00)\end{array}$ & $\begin{array}{c}120 \\
(100.00)\end{array}$ & $\begin{array}{c}0 \\
(0.00)\end{array}$ & $\begin{array}{c}0 \\
(0.00)\end{array}$ & $\begin{array}{c}120 \\
(100.00)\end{array}$ \\
\hline 12 & Intercropping & $\begin{array}{c}0 \\
(0.00)\end{array}$ & $\begin{array}{c}0 \\
(0.00)\end{array}$ & $\begin{array}{c}120 \\
(100.00)\end{array}$ & $\begin{array}{c}0 \\
(0.00)\end{array}$ & $\begin{array}{c}0 \\
(0.00)\end{array}$ & $\begin{array}{c}120 \\
(100.00)\end{array}$ & $\begin{array}{c}0 \\
(0.00)\end{array}$ & $\begin{array}{c}0 \\
(0.00)\end{array}$ & $\begin{array}{c}120 \\
(100.00)\end{array}$ & $\begin{array}{c}0 \\
(0.00)\end{array}$ & $\begin{array}{c}0 \\
(0.00)\end{array}$ & $\begin{array}{c}120 \\
(100.00)\end{array}$ \\
\hline 13 & Disease control & $\begin{array}{c}5 \\
(8.33)\end{array}$ & $\begin{array}{c}28 \\
(46.67)\end{array}$ & $\begin{array}{c}33 \\
(55.00)\end{array}$ & $\begin{array}{c}8 \\
(13.33)\end{array}$ & $\begin{array}{c}28 \\
(46.67)\end{array}$ & $\begin{array}{c}24 \\
(40.00)\end{array}$ & $\begin{array}{c}4 \\
(6.67)\end{array}$ & $\begin{array}{c}30 \\
(50.00)\end{array}$ & $\begin{array}{c}26 \\
(43.33)\end{array}$ & $\begin{array}{c}8 \\
(13.33)\end{array}$ & $\begin{array}{c}37 \\
(61.67)\end{array}$ & $\begin{array}{c}15 \\
(25.00)\end{array}$ \\
\hline 14 & Pest control & $\begin{array}{c}4 \\
(6.67)\end{array}$ & $\begin{array}{c}33 \\
(55.00)\end{array}$ & $\begin{array}{c}23 \\
(38.33)\end{array}$ & $\begin{array}{c}10 \\
(16.67)\end{array}$ & $\begin{array}{c}25 \\
(41.67)\end{array}$ & $\begin{array}{c}25 \\
(41.67)\end{array}$ & $\begin{array}{c}2 \\
(3.33)\end{array}$ & $\begin{array}{c}25 \\
(41.67)\end{array}$ & $\begin{array}{c}33 \\
(55.00)\end{array}$ & $\begin{array}{c}6 \\
(10.00)\end{array}$ & $\begin{array}{c}30 \\
(50.00)\end{array}$ & $\begin{array}{c}24 \\
(40.00)\end{array}$ \\
\hline
\end{tabular}

*FA=Full adoption, $\mathrm{PA}=$ Partial adoption, NA=No adoption 
Table.3 Problems in adoption of recommended practices of vegetables faced by the farmers of flood prone areas

\begin{tabular}{|c|c|c|c|}
\hline $\begin{array}{l}\text { Sl. } \\
\text { No. }\end{array}$ & Problems & $\begin{array}{l}\text { Number of } \\
\text { farmers }\end{array}$ & Rank \\
\hline 1. & $\begin{array}{l}\text { No opportunity for training on scientific vegetable cultivation } \\
\text { practices }\end{array}$ & $\begin{array}{c}52 \\
(86.66)\end{array}$ & I \\
\hline 2. & Lack of technical guidance from extension agents & $\begin{array}{c}49 \\
(81.66)\end{array}$ & II \\
\hline 3. & Inadequate irrigation facilities & $\begin{array}{c}47 \\
(78.33)\end{array}$ & III \\
\hline 4. & High cost of chemicals & $\begin{array}{c}47 \\
(78.33)\end{array}$ & III \\
\hline 5. & Lack of market information & $\begin{array}{c}46 \\
(76.66)\end{array}$ & IV \\
\hline 6. & Non-availability of quality seeds in proper time & $\begin{array}{c}45 \\
(75.00)\end{array}$ & V \\
\hline 7. & Non-availability of proper farm implements for mechanization & $\begin{array}{c}44 \\
(73.33)\end{array}$ & VI \\
\hline 8. & Threat from stray animals & $\begin{array}{c}35 \\
(58.33)\end{array}$ & VII \\
\hline 9. & Siltation in the field due to flood & $\begin{array}{c}33 \\
(55.00)\end{array}$ & VIII \\
\hline 10. & No facility for soil testing & $\begin{array}{c}32 \\
(53.33)\end{array}$ & IX \\
\hline 11. & High cost of hired labour & $\begin{array}{c}31 \\
(51.66)\end{array}$ & $\mathrm{X}$ \\
\hline 12. & Ignorance to select suitable crops according to soil type & $\begin{array}{c}16 \\
(26.66)\end{array}$ & XI \\
\hline 13. & $\begin{array}{l}\text { Degradation of soil health due to continued use of chemical } \\
\text { fertilizer }\end{array}$ & $\begin{array}{c}12 \\
(20.00)\end{array}$ & XII \\
\hline
\end{tabular}

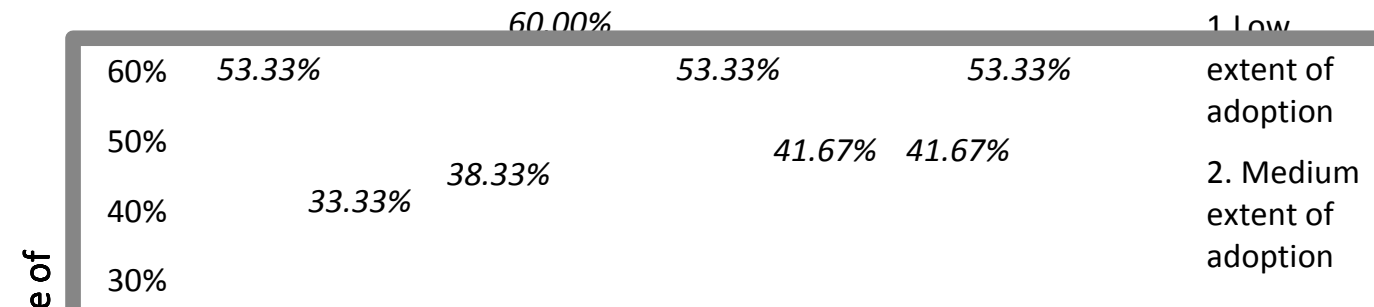

$13.33 \%$

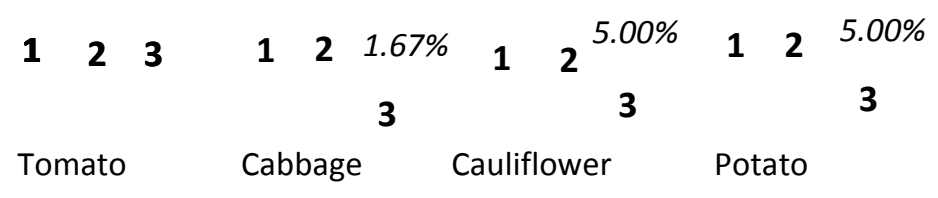

Fig.1 Percentage distribution of respondents according to extent of adoption of recommended practices of four major vegetables 
Finding revealed that majority of the farmers were found to have medium overall extent of adoption (45.00\%) followed by low overall extent of adoption (30.00\%) and high overall extent of adoption $(25.00 \%)$ of recommended practices of four major vegetables. In case of tomato, majority of the farmers were had low extent of adoption (53.33\%) followed by medium extent of adoption (33.33\%) and high extent of adoption (13.34\%) of recommended practices of tomato cultivation. In case of cabbage, majority of the farmers were found with medium extent of adoption $(60.00 \%)$, followed by low extent of adoption (38.33\%) and high extent of adoption (1.67\%) of recommended practices of cabbage cultivation. In case of cauliflower, majority of the farmers had low extent of adoption $(53.33 \%)$, followed by medium extent of adoption (41.67\%) and high extent of adoption $(5.00 \%)$ of recommended practices of cauliflower cultivation. In case of potato, majority of the farmers of flood prone areas were found with medium extent of adoption $(53.33 \%)$, followed by low extent of adoption $(41.67 \%)$ and high extent of adoption (5.00\%) of recommended practices of potato cultivation.

\section{References}

Baruah, M.J. (2004). A study on differential adoption behaviour of farmers in diversified farming practices under Sonitpur district of Assam. Unpublished M.Sc. (Agri) thesis, Deptt. of Extn. Edn., FA, A.A.U., Jorhat.

Rogers, E.M. (1983). Diffusion of Innovations $\left(3^{\text {rd }}\right.$ ed.), The Free Press, New York.

\section{How to cite this article:}

Kangkana Borah, Pabitra Kumar Das and Indrajit Barman. 2020. A Study of Adoption Pattern of Recommended Practices for Major Vegetable Crops in Flood Prone Areas of Lakhimpur District of Assam, India. Int.J.Curr.Microbiol.App.Sci. 9(06): 3686-3694. doi: https://doi.org/10.20546/ijcmas.2020.906.435 